\title{
BUILDING CHARACTER EDUCATION USING THREE MATRA OF HASAN AL-BANNA'S PERSPECTIVE IN PESANTREN
}

\author{
Hasan Baharun \\ Nurul Jadid University \\ Karanganyar, Paiton, Probolinggo, Jawa Timur, Indonesia, 67291 \\ Email: ha54nbaharun@gmail.com
}

\section{Siti Maryam}

Nurul Jadid University

Karanganyar, Paiton, Probolinggo, Jawa Timur, Indonesia, 67291

Email: mariaahaselalu@gmail.com

Received: 05, 2018. Accepted: 01, 2019. Published: 01, 2019.

\begin{abstract}
This study aimed to describe the efforts of Pesantren Nurul Jadid to implement of Hasan al-Banna's thought about Three Matra of education, namely the education of mind, body, and heart (qalb), in constructing students' characters at Pesantren Nurul Jadid Paiton Probolinggo East Java. This research used a qualitative method of case study type. The results showed that; pesantren has implemented Three Matra by delivering education for mind, body, and heart for its santri. It has set the moto which is in line with Hasan al Banna's thought in building the character of students. It is supported by its vision and mission which was described in the trilogy of students and five/panca awareness of students, education and learning activity, habituation, making of regulation as the norm of binding and organizing activity students.
\end{abstract}

Keywords: Character Education, Hasan al-Banna, Pesantren, Three Matra

\begin{abstract}
ABSTRAK
Penelitian ini membahas tentang upaya membumikan pemikiran Hasan al-Banna tentang Three Matra Pendidikan, yaitu pendidikan akal, jasmani, dan hati (qalb) dalam membangun karakter santri di Pondok Pesantren Nurul Jadid Paiton Probolinggo Jawa Timur. Penelitan ini menggunakan metode kualitatif dengan teknik studi kasus. Hasil penelitian menunjukkan bahwa; pemikiran Hasan al Banna dalam membangun karakter santri di Pondok Pesantren Nurul Jadid Paiton Probolinggo Jawa Timur, Indonesia dilakukan melalui pembuatan visi dan misi pesantren yang dijabarkan dalam trilogi santri dan panca kesadaran santri, kegiatan pendidikan dan pembelajaran, pembiasaan, pembuatan regulasi sebagai norma pengikat dan pengorganisasian aktivitas kegiatan santri.
\end{abstract}

Kata Kunci: Pendidikan Karakter, Hasan al Banna, Pesantren, Three Matra

\section{INTRODUCTION}

Pesantren plays a major role in building character in order to build a civilization in Indonesia (Rahem, 2018). It has been tested as an institution that helped shape the character and personality of the citizens of the nation. It is an Islamic subculture rooted in Islamic culture in Indonesia. It features not only educational and learning activities, but also instills a number of values or norms (Matondang, 2014). Ideally, Islamic education seeks to deliver humans to achieve a personal balance as a whole, namely the achievement of the balance of the dimensions of the function of the khalifah and 'abdulläh in a personal figure. This can be done through mental exercises, reason, intelligence, feelings, and senses.

In a nutshell, Islamic education seeks to develop all aspects of human life which include; spiritual, intellectual, imagination, scholarship, and others, both individually and in groups and 
provide encouragement for the dynamism of the above aspects, towards goodness and the achievement of the perfection of life, both in relation to al-Khalliq, fellow humans, and with nature. An Islamic scholar like Hasan Al-Banna proposes Islamic education which is based on several principles. Islamic education should serve as a basis to develop human resources. In addition, it should educate human to worship God. It promotes a good relationship between teacher and students. Curriculum and facilities should support the implementation of Islamic education (Jannah, 2017).

Along with the development of the era and globalization, pesantren as a manifestation of traditional Islamic education in Indonesia (Suheri \& Nurrahmawati, 2018) has undergone a fundamental change, that is; change from traditional to modern. This change has led to a dichotomized pesantren, into traditional pesantren, known to use the salafi system (studying kitab kuning) and the modern pesantren, which no longer only teaches the classical Islamic books, but offers more than that. The existence of the current globalization and the development of the era does not necessarily make pesantren lose its orientation. In fact, pesantren, especially modern ones adapt to the rules of modernity. it is widely known that the modern world causes three things at once: globalization, denationalization, and social reflexivity (Setiawan, 2013).

One of the pesantren that implements character education is Nurul Jadid in Probolinggo. Pesantren Nurul Jadid Paiton, Probolinggo nurtures character education for santri which is conducted in a planned and systematic manner. It upholds character education referring to character values that creates conducive social dynamics and is able to contribute to shaping religious communities in Indonesia. Students in the pesantren are expected in their daily lives in interacting with surrounding communities to exhibit behaviors such as tawädlu', qanāala,

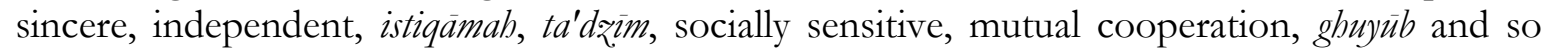
on.

Pondok Pesantren Nurul jadid is a fast-growing pesantren that has its own uniqueness in Probolinggo, East Java, Indonesia. Its uniqueness can be seen from the existence of pesantren in developing the potential of santri which includes "the heart, mind and body", which are developed simultaneously through systematically planned education and learning. All three of these are Hasan al-Banna's concepts known as the Three Matra, which in totality are developed in Pesantren Nurul Jadid through the vision and mission of the pesantren, which is integrated in the "trilogy concept" and "the five consciousness of santri".

Nurul Jadid has a special program offered to society because it has generated students who have strong scientific, religious and religious knowledge in the community. In addition, Nurul Jadid features cultural heterogeneity and diversity in its pesantren. It has shown its success in building the character of santri in accordance with the expectations of the community.

To create a quality and civilized education, there is a call for character building which should be designed in a planned, totality and systemic in each unit and level of education. Character building in educational activities can be done in various ways, such as self-control, empathy, obedience and moral reasoning (Abu et al., 2015). Character education can usually be shaped by education, experience, habituation, and environmental influences (Baharun \& Ummah, 2018). It can be understood as a planned effort to help people to understand, care, and act on ethical/moral values (Asmani, 2011)

Several studies investigating character education implementation in pesantren have been conducted by researchers. A study on character education using Hasan al-Banna perspective is an under research topic in an institution like pesantren. This study tries to fill the gap. It was aimed at exploring how the Three Matra Hasan al-Banna was implemented in Pesantren Nurul Jadid. 


\section{METHOD}

This research was aimed at investigating pesantren effort to implement Hasan al-Banna perspective namely Three Matra of Education. To achieve this objective, this study used qualitative research approach with case study design. The study took place at Pesantren Nurul Jadid Paiton, Probolinggo, East Java. Participants of the study included kiai and ustadz in pesantren. It collected data using; observation, focused group discussion and documentation. In addition, it applied interview to gain more sophisticated data from the site. Having collected the data, it analyzed them through several stages. First data reduction to meet the demand and objectives of the study. Next stage is data display to make sure that research question of the study had been answered. Finally, this study concluded the result.

\section{RESULTS AND DISCUSSION}

\section{Overview of Pesantren Nurul Jadid}

This study was aimed at investigating the implementation of Three Matra Hasan AlBanna in Pesantren Nurul Jadid. It found that pesantren strengthened character education based on "Three Matra" Hasan al-Banna through education and learning activities. In addition, pesantren focused on strengthening the five consciousness's and santri trilogy to achieve its vision. It applied the concept of Hasan Al-Banna in various educational and advocacy activities, both formal education institutions and non-formal education institutions ranging from the lower to the upper levels, such as Islamic Elementary Schools, Islamic Senior High Schools, Middle Schools, Islamic Senior High Schools, Nurul Jadid Vocational Schools. Even at the higher education level, such as Nurul Jadid University and Ma'bad Aly. These educational institutions seek to achieve educational orientation which is aimed at strengthening the concepts of mind, body, and heart (qalb), how all three can work together. Likewise, with non-formal educational institutions, such as the Madrasah Diniyah Nurul Jadid, Bina Anaprasa Nurul Jadid Kindergarten, LPBA (Lembaga Pendidikan Bahasa Asing/Foreign Language Development Institution), the al-Qur'an science education center, which seeks to balance these three aspects into the noble character of the santri

This study found that pesantren applied two approaches to build the character of the santri through the Hasan Al-Banna. The two approaches are classical and non-classical. The former is a communication approach built by teachers and students in a classical manner as a form of Islamic boarding school, such as the method of sorogan, wetonan, bandongan, the method of uswatun hasanah, manidhah hasanah and so on. The latter refers to an approach to communication between teachers and students involving media and other sources. This approach is carried out using technological media, the use of innovative and creative learning resources, and so forth.

This study found that the most visible distinctive approach in strengthening student character in pesantren through $W$ ali $A$ sub that means a personal approach between ustadz and santri. Wali Asub which served as a medium to strengthen the character of santri consisted of several administrators appointed by pesantren under the coordination of the head of the Guidance and Counseling section, who has the task of fostering santri spiritual and emotional. This approach was done in a structured and systematic manner. To nurture santri spiritual formation, pesantren conducted some activities like Qur'an recitation, al-Furüdl al-Äiniyah, and moral santri habit. While the emotional formation of santri, pesantren developed santri in the aspect of character formation, as well as provided a counselor for students who lacked discipline in obeying the pesantren rules. In addition, carers have the exact same duties as parents to their children, so their existence has a central role in the education and formation of santri in pesanten. 
There are some roles that ustadzplayed to nurture character education. Their role was to promote independent culture to santri in the pesantren, so that the santri would be more responsible and able to be independent in daily life in the pesantren. They were in charge of controlling, motivating, guiding and becoming a counselor in order to help the effectiveness of the implementation of Islamic boarding schools and santri's personal activities.

Pesantren evaluated character education using Hasan Al-Banna's principles. It carried out in a planned, systematic and tiered manner for each stage of evaluation. It implemented both formal and non-formal for educational institutions with continuous improvement principles.

Pesantren as Islamic educational institutions in Indonesia aims to foster Muslim individuals to have Islamic personalities. It provides students education on patterns of thought, attitudes, and action that are in line with Islamic education. Therefore, the basis of its education is moral formation. However, in traditional pesantren, this goal is not explicitly stated and written, but it is implicitly expressed in the form of material given, the processes, methods of teaching, and the norms that take place in the educational interactions it develops (Rizal, 2011).

\section{Implementing Three Matra Hasan al-Banna to Build Santri Character}

In an effort to implement "Three Matra" Hasan al-Banna concept, Pesantren Nurul Jadid designed and delivered the formulation of educational material for students to be achieved optimally. The educational material covered three aspects including Mind, body, and heart.

1. Educating Mind

First, educating the mind. The human mind is a potential that is quite urgent in a person because it is the basis benchmarks for determining good and bad responses to his actions. Therefore, the human requires some material science in order to be able to function properly. Hasan al-Banna gave serious attention to the development of students' intellect. The religionscience and its branches are educational material that can develop students' mind. The resource education material consists of religious science, natural sciences, and social knowledge along with its branches. The material of religious science is the first basis for students before he studies other sciences. However, the Three Matra should be studied by students to reach ma'rifatulläh.

Pesantren Nurul Jadid not only provided santri with religious knowledge but also general knowledge so that santri were not out of date. It managed Every single activity in the pesantren to support education, such as: reading the Islamic book in the morning, non-formal schools, formal schools and so on. These pesantren activities were aimed at achieving not only in the world but also in the hereafter. This is in accordance with the objectives of national education, namely: "to make smart the life of the nation and developing Indonesian people into human beings who have faith in God who is almighty and virtuous, possesses knowledge and skills, physical and spiritual health, solid and independent personality and responsibility social and national responsibility". This is in line with al-Qur'an: "Verily in the creation of the heavens and the earth, the alternation of night and day, the ark that sails in the sea brings what is useful to buman, and what God sends down water from the sky, then with it He revives the earth after death (dry) and he spreads on the earth all kinds of animals, and the wind and cloud-controlled range between beaven and earth; true (there are) signs (unity and greatness of God) for people who think" (QS. Al-Baqarah, [2]: 164).

The mind is one of the most important aspects of human beings. It distinguishes between humans and animals. It is a tool for thinking and deciding what is good and bad for a human. It is influenced by many things including food, people around and the science human studies. Human mind should not only be given general science, technology, but filled with the knowledge of religion (Helmawati, 2016). In this life, not all things can be measured and understood only by the mind, but it should be assisted by faith. Therefore, the first and foremost science that human beings need to give and study is religious knowledge. Because 
santri especially in Pesantren Nurul Jadid Paiton Probolinggo, should fill the reason with religious values that serve as their guide.

In Neuroscience, there are two categories of common sense, normal sense, and healthy sense. Everyone can have normal sense but not necessarily has a healthy sense. Normal sense means that the mind has the completeness in network function and has a normal capacity in general. Unlike healthy sense, a normal sense is not necessarily healthy. While healthy sense must be normal (Helmawati, 2016).

2. Educating Physic

Second, physical education. It needs to be maintained and developed for physical quality development. To achieve physical hygiene and health, it calls for physical education. Therefore, students should have the knowledge that can lead to the awareness of the importance of hygiene and health.

In relation to physical hygiene, Islam teaches its adherent to always maintain physical hygiene, home (room) and environment. These include not only human physic but also the environment where human lives. Islam teaches Muslim to pay attention to hygiene and cleanliness issue in their everyday life. This shows that a believer or a person who believes in Allah and His Messenger must always make sure that their physic and environment are clean (Ropi, 2012).

To implement physic education, pesantren train santri's independence to carry out their daily activities related to physical hygiene. To support their health, pesantren catered sports facilities that were available and accessible by students for instance: soccer, badminton volleyball, basketball, futsal and so on. Those sports options can be selected by santri depending on their own hobby and interest to ensure their healthy physic. In addition, the pesantren established Azzainiyah Clinic for all santri to provide health service for ill santri.

Pesantren take into consideration all activities to ensure the physical health of santri and their life skill. Physical health is a wonderful blessing for all human beings including santri. Healthy santri may contribute to pesantren improvement and reputation. They may compete and participate in any science and sports competition. They in many occasions were sent to various coaching and training program to improve their life skill both in regional and national levels. One of their achievement was national champion for football competition to prove their supremacy in physical education.

\section{Educating Heart}

Third, heart education (qalb). The potential of qalb or the heart of the students is an important concern in Hasan Al-Banna's education. one of the important goals of education is to build, encourage, and nourish the good heart. Many Problems distract students' heart in their life. The troublesome heart can be an obstacle in obtaining knowledge especially the ultimate knowledge for the human to achieve spiritually that is ma'rifatullah.

Heart plays a pivotal role in human life. It is not a visible organ like other human organs. Even though it is invisible in terms of its entity, it impact is paramount. According to al Ghazali, a heart is a delicate and divine element that is not visible to the physical eye and plays a very important role in analyzing a case or science human obtained (Al-Ghazali, 2011). This is in line with the Qur'an which means: "And verily We made for (most of the jinn and humans) they have hearts, but they are not used to understand (the Signs of Allab) and they bave eyes (but) they are not used to see (signs) Allab), and they have ears (but) they do not use to hear (the verses of Allab). they are like cattle, they are even more perverse. Those are the ones who are neglectful" (QS. al- A'raf [8]: 179).

Referring to this verse, it is clear that the heart is an important element that human need to take care and train to function well and support human daily activities. When a heart is not managed well by a human, human will behave worse and tend to act like an animal. This happens because of the great role that heart plays in human life. To avoid this bad 
circumstance to happen, human needs to manage the heart well. In line with this, Messenger of Allah affirms that human can be valued their morality whether they are good or bad depending on their heart condition. The Prophet says: "And indeed in one body there is a meat. If it is good, then all the members are good and if it is bad then all the members must be worse. Know it, it is the beart" (Al-Bukhori, 1998).

Islamic scholars have great attention regarding heart role in human life. For instance, AlGhazali and al-Muhasibi view the heart as the king who guards all human activities. A heart is closely associated with spirit, lust, and mind. It also directs the human five senses to activate in the good or wrong direction or to do good or evil. All this shows that the heart is very important in shaping human internal strength and human behavior (Jalil, 2016).

Pesantren taught santri Muraqqi $\%$-Ubudiyah. It is a classic book that is studied every day at pesantren. This classic book contains an explanation on how to arrange and manage the heart for right and good purpose. It explores three characters that serve as the mother of evil for the heart such as arrogant, riya' and envy or jealousy. To study this book, pesantren designed various methods, ranging from bandongan method, sorogan and takhassus. Translating Kitab Kuning using Bahasa Indonesia is also one method to learn the Islamic classic books.

\section{Stages to implement Character Education for Santri}

The concept of character education in pesantren can be implemented in several stages. First, santri should perform spiritual activities to clean their hearts (tazqiyat an-nafs), through dhiker, prayer together, praying congregation, istighasah or the like, in order to be ready in receiving materials or knowledge from ustad\%. When their heart is clean, they are given the material or science in accordance with what is needed. Of course, they will easily accept and understand the material or knowledge delivered by their ustadz. They will gain a deeper understanding and meaning to the knowledge they have obtained to be applied in real life. In addition, their understanding is supported by solid spiritual values (Baharun, 2017).

Teaching and learning in pesantren are dependent on several factors. Efforts to learn (and teach) as a scientific activity in pesantren, are believed to be only successful and worthy of worship is based on the sanctity of the heart of worldly affection. The efforts should be supported by the student's willingness to practice it.

Students need to know the priority scale of learning and the priority is based on how much religious benefit (ukhrawi) student can gain by something learned. On that basis, the pesantren classifies science on a normative-ethical basis. The classification ranges from almahmüdah (praised), al-madzmümah (the disgraceful), fardlu 'ain (obligatory for every Muslim individual) and fardlu kifäyah (obligatory for some Muslims). Moreover, in the Sufi context, the classification is also known for two types: 'ilm al-mu'amalah and ilm al-mukäsyafah. This scientific classification is closely related to the philosophy of the pesantren. The philosophy covers science, the human psyche, and charity, which is placed within the framework of ta'abbud to God, a process of spiritual achievement (Arif, 2008).

Qur'an has great attention to character education. Its emphasis on character education can be seen in many verses because of the importance of character education for Muslim. According to Yusuf Qardhawi, Islamic education is a whole human education process covering both intellect and heart; spiritual and physical; morals and skills. Islamic education pays attention to those human aspects because it prepares people to live with the society in peaceful circumstance and in a war situation. It also prepares people to face society with all its good and prosperity, sweet and bitter (Al-Qardhawi et al., 1980).

In general, the term character is often associated by people with a kind of temperament. The term gives emphasis on the psychosocial elements associated with education and the environmental context. It can be understood as the character from a behavioral standpoint that emphasizes the somatopsychic element that the individual possesses from birth (Hidayah, 
2018). From this point of view, it is considered the same as the personality. Personality is regarded as a characteristic feature, style, or disposition of a person, in particular, derived from the accepted forms of the environment. For instance the influence of the family in childhood and innate a person from birth (Otaya, 2014).

Lickona explained that "Character is defined as the nature of a person in responding to the situation morally. He emphasized three things in educating the character which is formulated beautifully: knowing, loving, and acting the good" (Lickona \& Wamaungo, 2012).

Lickona developed this theory to implement character education simultaneously: First, cognitive refers to the filling the brain. It means teaching people from ignorance to knowledge. It will enable them to cultivate the mind, and activate the function of the skill of intelligence. Second, effective which refers to feelings, emotions, the formation of attitudes within a person. The formation of attitudes may be in the form of sympathy, antipathy, love, hate, and so forth. This attitude can all be classified as emotional intelligence. Third, psychomotoric which is concerned with the actions, deeds, behaviors, and so on (Lickona \& Wamaungo, 2012).

Darmiyati Zuchdi mentions that "Character is a set of traits that are always admired as signs of goodness, virtue, and moral maturity of a person. He further argues that the purpose of character education is to teach certain traditional values, widely accepted values as the basis of good and responsible conduct. Therefore, character education is the realization of positive development as an individual (intellectual, emotional, social, ethical, and behavioral). All these values are aimed at helping humans become more complete and more perfect human beings (Zuchdi, 2008). In the same vein, according to Kemendikbud, a character is disposition, behavior, morality, or personality formed from the result of the internalization of various virtues are believed and used as a basis for the perspective, think, behave and act (Kemdikbud, 2013). It reveals that character education should not have special facilities, because what is needed is the process of awareness and habituation.

In the same vein, a project proposed six pillars of character education. Character Counts! Coalition (a project of The Joseph Institute of Ethics) has issued the Six Pillars of Character as follows (Chrisiana, 2005):

1. Trustworthiness, a form of character that inculcates values of integrity, honest, and loyal.

2. Fairness, a form of character that makes a person has an open mind and not prefer to take advantage of other persons.

3. Caring, a form of character that makes a person has a caring attitude and attention to others and social conditions of the surrounding environment.

4. Respect, a form of character that makes a person always appreciate and respect others.

5. Citizenship, a form of character that makes a person aware of laws and regulations and cares about the natural environment.

6. Responsibility, the form of character that makes a person responsible, disciplined, and always do things as well as possible.

Pesantren Nurul Jadid has its moto which is in line with Hasan al-Banna thought. Its motto says: "Mondok to study and build akblak karimah". It contains two keywords namely learning activity and building a noble character. These two terms are closely related with the thought of Hasan al Banna in building the character of santri. Pesantren has designed the motto to support its ideology. It stipulated in the trilogy of students and the five consciousness of santri.

\section{Upholding Trilogy of pesantren}

Pesantren upholds the trilogy of santri to support character education process. This trilogy covers: (Amin \& Ridwan, 1996):

1. Al-ihtimàm bil furūdh al-'ainiyah (pay attention to the obligatory actions of worship). 
2. Al-ibtimàm bi tark al-kabaiir (pay attention to leave the big sins).

3. Husnul adab ma'a alläh wa ma'a al khulqi (virtuous to Allah and to fellow-creatures of Allah).

The trilogy of santri in pesantren serve various purposes. It serves as a functioning value system which must be held firm by the santri in deepening knowledge in pesantren. In addition, it also becomes moral attitude which must be internalized as pesantren soul. These two functions ensure the process of learning and teaching are aimed at building santri character.

\section{Promoting Five Consciousness of Santri}

In an effort to build santri character, Pesantren Nurul Jadid also promoted the five consciousness of students santri namely (Amin \& Ridwan, 1996):

1. Religious Consciousness

Every santri must have extensive religious insight, high religious responsibility, and deep religious appreciation. This religious awareness covers three aspects; namely aqidah, worship, and morality.

In the aspect of aqidah, every santri must have a firm belief, that Allah is the Almighty and $\mathrm{He}$ has the right to be worshiped. It also sets that the Prophet Muhammad is the last prophet. For worship aspect, the santri are expected to worship only to Allah in several activities such as prayer, fasting, rakat, and Hajj. Last aspect concerning moral, it is recommended that the santri have a high moral awareness. The Prophet said: "I was sent to a perfect noble character". Furthermore, the Prophet said "addabani rabbi fa absana ta'dibi". The moral here is not only about personal morals, but also social morals, such as social order, amar ma'ruf nabi mungkar and moral discipline in the family and so on.

To implement religious awareness, pesantren has included this in the realm of mind and heart education for santri. Pesantren supports mind education with the knowledge of religion. This is to say that santri heart also needs guidance related to religion. It ensures that santri heart and mind should be good to achieve their learning activity. It is clear that the concept of the Three Matra Hasan al-Banna dimensions is very much in line with the educational activities and orientation in Pesantren Nurul Jadid.

2. Knowledge awareness

Pesantren accepts that Science can be divided into two, namely religious science and worldly knowledge. Santri are expected to master the two kinds of knowledge. If it is not possible, then the knowledge in the field of religion must synergize with worldly knowledge in building this nation, in order to create baldatun thayyibatun wa rabbun ghafur. As part of this awareness, pesantren teaches both of these sciences. In madrasas, santri are not only taught religion but also taught general science. On the other hand, in the school, santri are not only taught general science, but also religion.

3. Nation and state awareness

This awareness refers to the love of the homeland. In Pesantren Nurul Jadid, this awareness has been embedded in every individual in the pesantren, starting from the Kyai to the santri. Historically, the founder of the pesantren, K.H. Zaini Mun'im actively participated in fighting colonial to gain Nation independence.

The founder of pesantren has been a good example for santri to nourish their love to the country. This spirit is possessed by the santri; so that the santri will feel ownership of their nation. For santri, "to love the homeland is part of the faith". Nation and state awareness is included in their heart education to foster a spirit to become human beings who are useful for religion, and nation.

4. Community Awareness

Pesantren and Kiai should not be ivory towers far from the people. It should mingle and unite with the community. This means that pesantren are part of the community. Thus, people feel that they have pesantren and pesantren feel that they are part of a community. It entails that 
there is no "distance" between the pesantren and the community. If the santri and pesantren and the community feel that they belong to each other, then all forms of pesantren activities will get support from the community.

Santri in this pesantren came from various cities and regions and they will someday go home and return to their community. Therefore, santri must have sensitivity in interacting with their community. Santri must be able to plunge and foster and build their communities in a better direction, in accordance with Islamic principles and values

5. Organizational Awareness

Awareness of the importance of organization is absolute for santri in Pesantren Nurul Jadid. This is based on the Islamic concept of the importance of an organization as an effort to achieve the desired goals. The founder of Pesantren Nurul Jadid wanted to create students who have awareness, ability and organizational insight which are very relevant to the needs of the people.

Organizational awareness is included in the realm of mind education. The santri of Nurul Jadid must be able to be active in the organization. It is expected that santri learn organizations to achieve a common goal. The organization is a pattern of relationships that are interrelated between one part and another, which prioritizes communication and coordination in carrying out its activities to achieve common goals.

The five awareness of the santri serves as its distinction to develop pesantren. Santri are demanded to behave based on the trilogy of the santri and the five awareness of santri as the guideline. The trilogy of the santri and the five awareness of the santri of Nurul Jadid are closely related to the three concepts of Hasan al-Banna's dimension.

Pesantren's vision and mission are described in the trilogy of santri and the consciousness of santri. Its vision and mission serve as a general goal of education and mentoring activities to santri in pesantren. To achieve that goal, Pesantren Nurul Jadid also sought to instill faith and devotion to God and akblaq karimah. It also developed students' education, knowledge, talents, skill and expertise development, entrepreneurship and self-reliance. Moreover, it builds students' awareness of healthy living, the environment, the cultivation of community responsibilities and nationality (Baharun, 2006)

Hasan al-Banna believes that Character as "an individual's pattern of behavior set of values that leads to a system, which underpins the thoughts, attitudes, and behaviors displayed (Komalasari \& Saripudin, 2018). He also argued that it is impossible that there will be a revival of the ummah, without moral education, which is the pillar of teachers in the development of individuals, communities, and nations. In this moral formation, he himself had emphasized various ways in the souls of his followers (Muizzuddin, 2017). Among his statements are as follows: "The emerging people need the noblest character, the great soul, and high ideals because they will face the demands of a new society."

Pesantren Nurul Jadid designed several activities for santri. It educated santri 24 hours through various religious activities, lifeskill, and general knowledge, starting from morning to night. These are typical of pesantren teaching and learning activity (Moh. Rifa'i, 2017). The education given to them is intended to give birth to individuals who are not easy to give up in the face of life, as long as it is related to goodness, thus making them as reliable santri figures for the nation's future.

Hasan al-Banna presented his Islamic principles which he encouraged to be realized and preserved (Larsson, 2017). In his view, the purpose of Islamic education is oriented to realize the identity of Islam, shaping the Muslim personality (ar-Rijäl al-Muslimün). Then the Muslim personality by Hasan al-Banna is formulated as an individual who is not only an expert in worship but also social sensitivity which is a form of Islamic teaching that reflects Islam as a social order must be applied in life. Furthermore, there are three elements that an individual 
needs to build in order to achieve a noble character. The first element is Muslim individual. It builds up the second element which is Muslim family. Having built the two elements, Muslim strive to build Muslim society (Hashim et al., 2015).

The message of al-Banna's preaching related to the aqidah, sharia, and morals. His message of da'wah can be explained among others: the message of the faith in theological discourse, the message of sharia in the discourse of power and the moral message in the discourse of social relations (Fuadi, 2017). His views on the moral aspect have been deemed as the most important aspect which is considered the first milestone for the change of society. Therefore character education should be continually implemented from primary education to university level (Novianti, 2017). He proposed the so-called "commander of change" for Muslim that is pious and has a noble position. To achieve this, Muslim should exhibit good moral in the eyes of man and Allah.

Pesantren, hailed as an Islamic educational institution derived from Islamic tradition needs to be developed to respond to moral degradation which may occur in pesantren environment recently. Therefore, it needs to be more intent to improve the guidance of abklake karimah for santri in Islamic boarding school. Akblak karimah and character is the purpose of education in Islamic boarding schools that have the same orientation, namely the formation of santri characters. Although they have different names, they refer to a similar entity.

The purpose of pesantren education is not only to enrich the students' minds with explanations but also seeks to explore several purposes. Other purposes of pesantren education are: to elevate morals, to train and heighten the spirit, to appreciate spiritual values and humanity, to teach honest and moral attitudes and behavior, and to prepare students for a simple life with good heart. Its objective is not to pursue the interests of power and money. It is imparted to students that learning is solely a duty and devotion to God. It directed and guide personality of the santri themselves as servants of Allah.

Pesantren with the trust of the community, it always embodies the three functions attached to it. There are three functions of pesantren namely: First, as a medium of cadre for religious thinkers (center of excellence). Second, as an educational institution for religion human resources. Thirdly, as an institution that conducts community empowerment. In addition, it is also understood as part of a social change agency amid the changes that occurred in Indonesia (Baharun, 2006).

Pesantren is the oldest Islamic educational institution that spread nation-wide. It has become the center of the formation of a religious man, especially in the formation of the character of the nation. In this case, it is a religious institution that nurtures character education that should be developed to achieve the expected national education objectives. By combining several disciplines, it has been believed by the wider community that it is able to make human beings successful both worldly and ukhrawi. Baharun acknowledges that Pesantren Nurul Jadid educated santri with some good habits and provided organizational education. It also facilitated learning system, regulation as a binding activity of santri. Santri followed this pesantren education and they were expected to absorb the result of three aspects (Three Matra) of Hasan al-Banna's thought that includes mind, body, and heart. These Three Matra have gone hand in hand with pesantren activities to build the character of students in pesantren.

\section{CONCLUSION}

Pesantren are Islamic educational institutions that have succeeded in producing graduates with a noble character and should be used as a reference in the development of education in Indonesia. Nurul jadid has the orientation of education in developing its center character. It implemented the education for mind, body, and heart. These Three Matra education are expected to generate santri to be human beings who are independent and useful to society, the 
nation, and religion. Hasan Al Banna's conception reinforces the direction of developing pesantren education in the current disruptive era, where strength and unity between mind, body, and heart are needed. with the merging of these three great powers, humans will be born who have multi competencies, character and civilized.

\section{BIBLIOGRAPHY}

Abu, L., Mockhtar, M., Hassan, Z., \& Suhan, S. Z. D. (2015). How to develop character education of madrassa students in Indonesia. Journal of Education and Learning, 9(1), 7986. http://dx.doi.org/10.11591/edulearn.v9i1.768

Al-Bukhori, A. A. M. B. I. (1998). Shabih bukhari. Riyadh: Darussalam.

Al-Ghazali. (2011). Ibya' ulumiddin. Al-Qahirah: Dar al-Hadith.

Al-Qardhawi, Y., Gani, H. B. A., \& Ahmad, Z. A. (1980). Pendidikan Islam dan madrasah Hasan Al-Banna. Bulan Bintang.

Amin, M. M., \& Ridwan, M. N. (1996). KH Zaini Mun'im; Pengabdian dan karya tulisnya. Yogyakarta: LP3S.

Arif, M. (2008). Pendidikan Islam transformatif. LKIS Pelangi Aksara.

Asmani, J. M. (2011). Buku panduan internalisasi pendidikan karakter di sekolah. Diva Press.

Baharun, H. (2006). Manajemen strategi peningkatan mutu pendidikan pondok pesantren (studi di pondok. pesantren Nurul Jadid Paiton Probolinggo). Tesis, konsentrasi Manajemen Pendidikan Islam, Program Pascasarjana.

Baharun, H. (2017). Total moral quality: A new approach for character education in pesantren. Ulumuna, 21(1), 57-80. https://doi.org/10.20414/ujis.v21i1.1167

Baharun, H., \& Ummah, R. (2018). Strengthening students' character in akhlaq subject through problem based learning model. Tadris: Jurnal Keguruan Dan Ilmu Tarbiyah, 3(1), 21-30. https://doi.org/10.24042/tadris.v3i1.2205

Chrisiana, W. (2005). Upaya penerapan pendidikan karakter bagi mahasiswa (studi kasus di jurusan teknik industri uk petra). Jurnal Teknik Industri, 7(1), 83-90. https://doi.org/10.9744/jti.7.1.pp.\%2083-90

Fuadi, M. H. (2017). Pesan dakwah Hasan Al-Banna dalam buku Majmu'at Al-Rasail. Ilmu Dakwah: Academic Journal for Homiletic Studies, 11(2), 325-340. https://doi.org/10.15575/ idajhs.v12i.2418

Hashim, Z., Kadir, F. A. A., \& Yusoff, Y. M. (2015). Pendekatan Hasan Al-Banna dalam pembangunan insan menerusi Majmu'at Al-Rasail. Jurnal Hadhari: An International Journal, $7(2), 49-62$.

Helmawati. (2016). Pendidik sebagai model (menjadikan anak sehat, beriman, cerdas dan berakblak mulia). Bandung: Remaja Rosdakarya.

Hidayah, U. (2018). Rekonstruksi evaluasi pendidikan moral menuju harmoni sosial. Pedagogik: Jurnal Pendidikan, 5(1), 69-81.

Jalil, M. H. (2016). Konsep hati menurut Al-Ghazali. Reflektika, 11(1), 59-71. Retrieved from ejournal.idia.ac.id/index.php/reflektika/article/download/37/33

Jannah, R. (2017). Pemikiran pendidikan Islam Hasan Al-Banna. Journal Analytica Islamica, 6(1), 66-76. Retrieved from jurnal.uinsu.ac.id/index.php/analytica/article/download/ $1269 / 1032$

Kemdikbud. (2013). Pembinaan karakter di sekolah menengah pertama. Jakarta: Kemendiknas.

Komalasari, K., \& Saripudin, D. (2018). The influence of living values education-based civic education textbook on students' character formation. International Journal of Instruction, 11(1), 395-410. https://doi.org/10.12973/iji.2018.11127a

Larsson, T. (2017). The Islamist Ideology of Hassan al-Banna and Sayyid Qutb A Comparative Analysis. University of OSLO. 
Lickona, T., \& Wamaungo, J. A. (2012). Mendidik untuk membentuk karakter: bagaimana sekolab dapat memberikan pendidikan tentang sikap hormat dan bertanggungjawab. Jakarta: Bumi Aksara.

Matondang, Z. (2014). Pembentukan karakter santri/wati berbasis tradisi pesantren. Pelangi Pendidikan, 21(1). https:// doi.org/10.24114/pelangi.v21i1.2744

Moh. Rifa'i. (2017). Community empowerment in Islamic boarding school (pemberdayaan masyarakat dalam meningkatkan mutu pendidikan). Probolinggo: CV. Mandiri.

Muizzuddin, M. (2017). Metode pendidikan moral menurut Hasan Al Banna. MIYAH: Jurnal Studi Islam, 11(1), 100-112. Retrieved from https://ejournal.inkafa.ac.id/index.php /miyah/article/view/8/8

Novianti, N. (2017). Teaching character education to college students using bildungsromans. International Journal of Instruction, 10(4), 255-272. https://doi.org/10.12973/ iji.2017.10415a

Otaya, L. G. (2014). Pendidikan karakter berbasis nilai. Nadwa, 8(1), 75-94. Retrieved from http://journal.walisongo.ac.id/index.php/Nadwa/article/viewFile/571/518

Rahem, Z. (2018). Menggali paradigma pendidikan berkeadaban dari kitab Ayyuha Al-Walad dan Kimiatus Sa'adah. Jurnal Islam Nusantara, 2(1), 60-71. Retrieved from http://jurnalnu.com/new/index.php/as/article/view/70

Rizal, A. S. (2011). Transformasi corak edukasi dalam sistem pendidikan pesantren, dari pola tradisi ke pola modern. Jurnal Pendidikan Agama Islam-Ta'lim, 1051(9), 95-112. Retrieved from https://bit.ly/2Df4BJI

Ropi, I. (2012). Pendidikan agama Islam. Jakarta: Kencana Prenada Group.

Setiawan, E. (2013). Modernisasi pola sistem pendidikan pesantren (studi kasus pondok pesantren modern daarul fikri Mulyoagung dau Malang). ULUL ALBAB Jurnal Studi Islam, 14(2). https://doi.org/10.18860/ua.v14i2.2656

Suheri, \& Nurrahmawati, Y. T. (2018). Model pendidikan multikultural di pondok pesantren. Pedagogik: Jurnal Pendidikan, 5(1), 32-49. https://ejournal.unuja. ac.id/index.php/ pedagogik/ article/view/217/172

Zuchdi, D. (2008). Humanisasi pendidikan. Jakarta: Bumi Aksara. 